\title{
PERBEDAAN STRATEGI KESANTUAN DALAM PERCAKAPAN UNTUK PEMBELAJAR BAHASAJEPANG TINGKAT SHOKYUU DAN TINGKAT CHUUKYUU
}

\author{
Reny Wiyatasari dan Maharani P.Ratna \\ Fakultas Ilmu Budaya Universitas Diponegoro
}

Email: reny.wiyatasari@gmail.com dan maharanipr_yellow@yahoo.co.id

\begin{abstract}
The purpose of this paper is to know the politeness strategy dan expressions which are exist in expressions contain of politeness strategy in Japanese conversation class for basic level and intermediate level. The data sources are the conversation part of book titled Minna No Nihongo Shokyuu 2 dan Minna No Nihongo Chuukyuu 1. Based on the analysis result, there are 110 datas found in basic level, and 68 datas are found in intermediate level. As a result, positive politeness strategy (sub strategy 2) is the most found politeness strategy in basic level, while negative politeness strategy (sub strategy 1) is the most found politeness strategy in intermediate level. The type of expressions that are found in expressions contain of positive politeness strategy (sub strategy 2), such as 〜ndesuka ( んですか), 〜 desuka (〜ですか), while the type of expressions that are found in expressions contain of negative politeness strategy (sub strategy 1), such as Chotto te mo ii desuka (ちょっと〜てもいいですか), Chotto te itadakenaideshouka (ちょっと〜ていただけないでしょうか).
\end{abstract}

Keywords : politeness strategy, positive politeness, negative politeness, shokyuu, chuukyuu

\section{LATAR BELAKANG}

Pada pembelajaran mata kuliah berbicara atau kaiwa (会話) dalam bahasa Jepang, pembelajar tidak hanya mendapat kesempatan untuk mempraktekkan bahasa Jepang, namun juga mendapat pengajaran mengenai cara berdialog dengan santun. Kesantunan dalam dialog diajarkan melalui beberapa situasi ujar atau bamen (場面) yang jauh, dll. Melalui bamen, mahasiswa dapat mempelajari perbedaan tingkat kesantunan ketika berdialog dengan lawan bicara.

Berdasarkan hal tersebut, penelitian mengenai strategi kesantunan (selanjutnya SK) perlu dilakukan guna mengetahui jenis SK dan bentuk-bentuk ungkapan yang terdapat dalam tuturan yang mengandung SK pada pembelajaran percakapan tingkat shokyuu( 初級) dan pembelajar tingkat untuk memudahkan mahasiswa mempelajari kesantunan dalam bahasa Jepang. Bamen yang dimunculkan pada umumnya memunculkan bamen yang berhubungan dengan orang yang lebih superior, bamen yang berhubungan dengan suasana kerja, bamen yang berhubungan dengan orang dengan jarak sosial menengah atauchuukyuu (中級). Sebagai sumber data, penelitian ini menggunakan buku Minna No Nihongo Shokyuu 2 dan Minna No Nihongo Chuukyuu 1. Penelitian ini diharapkan dapat memberikan kontribusi bagi pembelajar bahasa Jepang dan peminat Linguistik, khususnya bagi mereka yang berminat pada cabang ilmu Pragmatik. 


\section{RUMUSAN MASALAH}

1. Jenis SK apa saja yang muncul dalam percakapan tingkatshokyuu dan chuиkyuu?

2. Ungkapan apa saja yang digunakan pada SK dalam percakapan tingkat shokyuu dan chuukyuu?

\section{LANDASAN TEORI}

\subsection{Pragmatik dan Konteks}

Pragmatik atau goyoron (語用論) adalah disiplin ilmu yang mempelajari mengenai aspek hubungan antara bahasa dan konteks yang mengacu pada ketidaksesuaian penggunaan bahasa (Levinson, 1995: 9). Sedangkan konteks adalah hal mengenai bagaimana faktor linguistik, faktor sosial dan epistemis, saling berhubungan dengan bahasa sehingga menghasilkan makna (Cummings, 2007: 5) Beberapa cabang ilmu pragmatik diantaranya adalah deiksis atau chokuji (直示), prinsip kerjasamaatau kyouchou no genshoku (調の原則), tindak tutur atau hatsuwakoi (発話行為), konteks atau kontekusuto (コンテクスト),

kesantunan atau teineisa (丁寧さ)

\subsection{Kesantunan}

Brown dan Levinson (1987) telah mengembangkan teori yang menyatakan bahwa orang akan termotivasi oleh kebutuhan mereka untuk mempertahankan "harga diri" (face) mereka, yaitu kebutuhan untuk mendapatkan persetujuan atau penghargaan dari orang lain dan mempertahankan perasaan bahwa dirinya adalah berarti di hadapan orang lain (selfworth) (Black, 2011:153). Face dalam beberapa buku disebut dengan muka atau wajah. Wajah atau muka adalah citra diri seseorang di khalayak umum (public selfimage of a person). Wajah atau muka diartikan sebagai keadaan emosional atau citra diri setiap orang yang tidak boleh dipermalukan. Setiap orang memiliki naluri menjaga wajah atau mukanya. Jika seseorang kehilangan wajah, dia dianggap tidak memiliki harga diri sebagai satu individu dalam komunitasnya. Dengan demikian, kesantunan adalah situasi dalam interaksi yang di dalamnya pembicara menyadari wajah atau muka (face) mitra tuturnya. Hanya dengan menghormati mitra tutur, maka penutur juga akan mendapat penghormatan atau penghargaan dari mitra tuturnya.

Lebih lanjut Brown dan Levinson (1987: 61) menyatakan bahwa konsep tentang wajah atau muka ini bersifat universal, dan secara alamiah terdapat berbagai tuturan yang cenderung merupakan tindakan tidak menyenangkan yang disebut Face Threatening Act 'Tindakan Mengancam Muka' dan disingkat FTA, yaitu ucapan yang mengancam penghargaan atau pengharapan seseorang atas mukanya.

FTA ini dapat dibedakan menjadi tindakan mengancam muka positif mitra tutur dan tindakan mengancam muka negatif mitra tutur. Secara singkat, tindakan yang berpotensi mengancam muka negatif mitra tutur diantaranya tindakan yang terkandung dalam ungkapan-ungkapan seperti : order and request 'perintah dan permintaan', suggestion 'saran', advise 'nasehat', warning 'peringatan', offer 'tawaran', promise 'janji', compliment 'pujian', dsb. Sementara itu, tindakan yang berpotensi mengancam muka positif mitra tutur di antaranya tindakan yang terkandung dalam ungkapan-ungkapan seperti : disapproval 'ketidaksetujuan', criticism 'kritikan', contempt or ridicule 'merendahkan atau mempermalukan', challenges 'tantangan', mention of taboo topics 'penyebutan hal-hal yang bersifat tabu', bad news about $\mathrm{H}$ or good news about $\mathrm{S}$ 'kabar buruk tentang mitra tutur atau berita baik tentang penutur, dsb.

Brown dan Levinson membagi SK menjadi lima, yakni strategi langsung tanpa basa basi atau bald on record strategy, SK positif atau positive politeness strategy, SK negatif atau negative politeness strategy, strategi tidak langsung atau off record, dan strategi tidak mengancam muka atau don't do the FTA. Berikut ini adalah uraiannya: 
1. Strategi langsung tanpa basa basi. Strategi ini merupakan strategi dimana penutur melakukan FTA untuk menyatakan sesuatu dengan jelas. Penutur tidak memperdulikan muka lawan tuturnya. Strategi ini sering digunakan ketika penutur memiliki power yang lebih besar dalam suatu dialog dibanding mitra tuturnya.

2. SK positif. SK positif memiliki beberapa sub strategi, diantaranya:

a. Strategi pertama : perhatikan minat, keinginan, kelakukan, dan barangbarang mitra tutur.

b. Strategi kedua : buat suatu ketertarikan, persetujuan dan simpati kepada mitra tutur nampak/terlihat lebih besar atau lebih penting.

c. Strategi ketiga : tingkatkan rasa ketertarikan terhadap mitra tutur.

d. Strategi keempat : gunakan penanda atau sebutan yang menunjukkan identitas atau jati diri kelompok (bentuk sapaan, dialek, jargon atau slang).

e. Strategi kelima : cari dan mengusahakan persetujuandengan mitra tutur.

f. Strategi keenam : hindari ketidaksetujuan terhadap mitra tutur dengan berpura- pura setuju, persetujuan yang semu,berbohong untuk kebaikan, kata berpagar.

g. Strategi ketujuh: praanggapkan, munculkan, nyatakan persamaan persepsi

h. Strategi kedelapan : gunakan lelucon.

i. Strategi kesembilan : nyatakan ataupranggapkan bahwa penutur memahami keinginan mitra tutur.

j. Strategi kesembilan : nyatakan atau pranggapkan bahwa penutur memahami atau paham terhadap keinginan mitra tutur.

k. Strategi kesepuluh : beri tawaran dan janji.

1. Strategi kesebelas :tunjukkan rasa optimis'. m. Strategikeduabelas : libatkan penutur dan mitra tutur dalam suatu kegiatan atau aktifitas tertentu'.

n. Sub strategi keduabelas : libatkan penutur dan mitra tutur dalam suatu kegiatan atau aktifitas tertentu'

o. Sub strategi ketigabelas : berikan atau mintalah alasan

p. Sub strategi keempat belas : asumsikan atau nyatakan hubungan timbal balik.

q. Sub strategi kelima belas : berikan simpati pada mitra tutur.

3. Sedangkan SK negatif. SK negatif memiliki beberapa sub strategi, yakni:

a. Sub strategi pertama: gunakan ungkapan atau tuturan tidak langsung sesuai konvensi.

b. Sub strategi: gunakan bentuk pertanyaan dibatasi oleh partikel, kata atau frasa tertentu.

c. Sub strategi: bersikaplah pesismis

d. Sub strategi keempat: minimalkan tekanan terhadap mitra tutur.

e. Sub strategi kelima: berikan penghormatan.

f. Sub strategi keenam: gunakan permohonan maaf

g. Sub strategi ketujuh : pakailah bentuk impersonal

h. Sub strategi kedelapan: nyatakan tindakan mengancam muka sebagai aturan yang bersifat umum.

i. Sub strategi kesembilan: nominalisasikan

j. Sub strategi kesepuluh: nyatakan diri berhutang budi.

4. Strategi tidak langsung. Strategi ini memiliki beberapa sub strategi, yakni:

a. Sub strategi pertama: beri petunjuk dengan mengemukakan alasan melakukan tindakan.

b. Sub strategi kedua: asosiasikan petunjuk dengan menyebutkan sesuatu yang diasosiasikan pada tindakan yang diminta kepada lawan tutur.

c. strategi ketiga : mempresuposisikan maksud penutur. 
d. Sub strategi keempat: yatakan kurang dari yang sebenarnya dengan membatasi sejumlah atribut untuk mengimplikasikan sesuatu yang buruk

e. Sub strategi kelima: nyatakan suatu hal secara berlebihan dengan membesarbesarkan keadaan dari yang sebenarnya.

f. Sub strategi keenam: ulang tuturan tanpa menambah kejelasan dengan mengujarkan kebenaran yang paten dan penting.

g. Sub strategiketujuh: gunakan pertentangan mengemukakan kebenaran dan mendorong lawan tutur mendamaikan masalah.

h. Sub strategikedelapan: sindir dengan cara menyatakan maksud secara tidak langsung dan berlawanan.

i. Sub strategikesembilan: gunakan kiasan / metafora dengan menyembunyikan konotasi nyata dari tuturan yang dituturkan.

j. Sub strategikesepuluh: gunakan pertanyaan retorik dengan mengemukakan pertanyaan dari jawaban yang mengambang untuk menyatakan FTA.

k. Sub strategi kesebelas : gunakan tuturan dengan makna ganda.

1. Sub strategi keduabelas: samarkan objek FTA atau pelanggaran yang dilakukan

m. Sub strategiketigabelas: genaralisasikan secara berlebihan untuk menghindari FTA dengan mengemukakan peraturan umum

n. Sub strategi keempatbelas: gantikan mitra tutur dengan mengalamatkan FTA pada seseorang yang tidak mungkin terancam mukanya.

o. Sub strategi kelimabelas: ungkapkan secara tidak lengkap dengan menggunakan ellipsis.

5. Strategi tidak mengancam muka. Strategi ini dilakukan dengan cara tidak melakukan suatu tindakan yang mengancam muka mitra tutur.

\section{ANALISIS}

4.1 Jenis SK yang muncul dalam percakapan tingkat shokyuu dan chuukyuu.

Berdasarkan analisis, berikut ini adalah tabel SK yang muncul dalam percakapan tingkat shokyuu dan chuukyuu.

\begin{tabular}{|c|c|c|c|}
\hline No. & Jenis SK & $\begin{array}{l}\text { Jumlah } \\
\text { tuturan } \\
\text { shokyuu }\end{array}$ & $\begin{array}{c}\text { Jumlah } \\
\text { tuturan } \\
\text { chuukyuu }\end{array}$ \\
\hline 1. & Baldon recordstrategy & 16 & 8 \\
\hline 2. & SK positif(sub strategi 1) & 6 & 1 \\
\hline 3. & SK positif(sub strategi 2) & 20 & 3 \\
\hline 4. & SK positif(sub strategi 3) & 1 & 0 \\
\hline 5. & SK positif (sub strategi 5) & 6 & 2 \\
\hline 6. & SK positif(sub strategi 6 ) & 0 & 2 \\
\hline 7. & SK positif(sub strategi 7) & 1 & 0 \\
\hline 8. & SK positif (sub strategi 10 ) & 2 & 1 \\
\hline 9. & SK positif (sub strategi 11) & 1 & 0 \\
\hline 10. & SK positif(sub strategi 12) & 1 & 1 \\
\hline 11. & SK positif (sub strategi 14 ) & 1 & 0 \\
\hline 12. & SK positif (sub strategi 15 ) & 1 & 0 \\
\hline 13. & SK negatif (sub strategi 1) & 13 & 20 \\
\hline 14. & SK negatif (sub strategi 3) & 1 & 1 \\
\hline 15. & SK negatif (sub strategi 4) & 3 & 0 \\
\hline 16. & SK negatif (sub strategi 5) & 8 & 0 \\
\hline 17. & SK negatif (sub strategi 6) & 6 & 4 \\
\hline 18. & SK negatif(sub strategi 7) & 7 & 8 \\
\hline 19. & SK negatif(sub strategi 8) & 1 & 1 \\
\hline 20. & SK negatif(sub strategi 10) & 1 & 1 \\
\hline 21. & Bald off record strategy (sub strategi 1 ) & 3 & 4 \\
\hline 22. & Bald off record strategy (sub strategi 2 ) & 7 & 7 \\
\hline 23. & Bald off recordstrategy(sub strateg 3 ) & 2 & 1 \\
\hline 24. & Bald off record strategy (sub strategi 13) & 0 & 1 \\
\hline 25. & Bald off record strategy (sub strateg 15 ) & 2 & 2 \\
\hline & TOTAL & 110 & 68 \\
\hline
\end{tabular}

Berdasarkan tabel di atas, dapat diketahui bahwa terdapat 25 SK yang digunakan dalam percakapan tingkat shokyuu dan chuиkyuu. Untuk percakapan tingkat shokyuu ditemukan 110 data tuturan yang menggunakan SK, sedangkan dalam percakapan tingkat chuukyuuditemukan 68 data tuturan yang menggunakan SK. Dalam tingkat shokyuu, SK yang paling banyak digunakan adalah SK positif (sub strategi 2) dengan presentase kemunculan $18 \%$. Sedangkan dalam tingkat chuukyuu, SK yang paling banyak digunakan adalah SK negatif (sub strategi 1) dengan presentase kemunculan $29 \%$. 
4.2 Ungkapan yang digunakan pada SK dalam percakapan tingkat shokyuu dan chuukyuu.

Wujud tuturan SK strategi positif (sub strategi 2) yang merupakan SK yang paling banyak digunakan dalam percakapan tingkat shokyuu adalah hontou desu ka (本当です か), sugoi desu ne(すごいですね), subarashii yume desu ne (素晴らしい夢で すね, isshoni ikanain desu ka(一緒に行か ないんですか), betsu betsu ni sumun desu ka（別々に住むんですか）, taihen desu ne (大変ですね), sore wa ikemasen ne (それはいけませんね), kono biru mo omoshiroi desain desu ne (このビル面白い デサインですね)、seiri suru no ga jouzu nan desu ne (整理するのが上手なんです ね)、sou desu ka (そうですか), omiai no kaisha ga arun desu ka (お見合いの会社が あるんですか), hataraki sugi desu ne (働き すぎですね).

Berdasarkan hal di atas, dapat dipahami bahwa ungkapan-ungkapan yang digunakan pada SK strategi positif (sub strategi 2) diantaranya menggunakan bentuk-bentuk:

1. 〜ndesuka ( んですか)

2. 〜 desuka (〜ですか)

3. 〜 desu ne (〜ですね)

Wujud tuturan SK strategi negatif (sub strategi 1) yang merupakan SK yang paling banyak digunakan dalam percakapan tingkat chuukyuu adalah chotto, o-kiki shitemo ii desuka (ちょっと、お聞きしてもいいで 寸 か ), chotto, o-taku wo misete itadakenaideshouka (ちょっと、お宅を見 せていただけないでしょうか), chotto, oshiete itadakemasenka (ちょつと、教え ていただけませんか)、 dekireba, sensei no go tsugou no yoi hi ni henko sasete itadakenai deshouka (できれば，先生の ご都合のよい日に変更させていただけな いでしょうか)、modorimasu tara kochira kara o-denwa sashiagemashouka(戻ります たらこちらからお電話差し上げましょう か), ashita sakura geijutsu sentaa e ikou to omotteirun dakedo 、 dou yatte ikeba ii?
（明日桜芸術センターへ行こうと思って いるんだけど、どうやっていけばいい?, Senri de norikaete nishisenri de orireba iin jya nai(千里で乗り換えて西千里で降り ればいいんじゃない), sakura gejitsu sentaa e ikitain desu ga...dou ittara ii deshouka（桜芸術センターへ行きたいん ですが. . どう行ったらいいでしょう か), kachou, ima chotto yoroshii deshouka

(課長、今ちょっとよろしいでしょう か), are wo riyou dekinai deshouka（あれ を利用できないでしょうか）, isshoni itte mimasen ka （一緒に行ってみません か), kochira de matasete moraemasenka (こちらで待たせてもらえませんか)， toppusha no ga yoroshiin jya nai deshou ka (トップ社のがよろしいんじゃないでし ようか), okinawa to iu no wa dou?（沖縄 というのはどう?）, iroiro kangaeterun desu ga...doko ka osusume no tokoro arimasenka（色々考えてるんですが.... こかお勧めのところ、ありませんか）， pakkutsuaa wo riyou shitara dou? (パック ツアーを利用したらどう?）。

Berdasarkan hal di atas, dapat dipahami bahwa ungkapan-ungkapan yang digunakan pada SK strategi negatif (sub strategi 1) diantaranya menggunakan bentuk-bentuk:

1. Chotto te mo ii desuka (ちょっと〜て もいいですか)

2. Chotto te itadakenaideshouka (ちょっ と〜ていただけないでしょうか)

3. Chotto te itadakemasenka (ちょつと〜 ていただけませんか)

4. 〜mashouka (〜ましょうか)

5. Dou yatte baii? (どうやって〜ばい (?)

6. 〜 ba iin jya nai (〜ばいいんじゃない)

7. 〜 masenka (〜ませんか)

8. sasete moraemasenka ( 〜させてもら えませんか)

9. 〜 tara ii deshouka (〜たらいいでしょ うか)

10. naideshouka (〜ないでしょうか)

11. njyanai deshouka (〜んじゃないでし ようか)

12. toiu no wa dou (〜というのはどう?)

13. tara dou? (〜たらどう?) 


\section{SIMPULAN}

Berdasarkan analisis, dapat diperoleh simpulan sebagai berikut:

1. Jenis SK yang muncul dalam percakapan tingkat shokyuu dan chuukyuu adalahbald on record strategy, SK positif (sub strategi 1), SK positif (sub strategi 2), SK positif (sub strategi 3), SK positif (sub strategi 5), SK positif (sub strategi 6), SK positif (sub strategi 7), SK positif (sub strategi 10), SK positif (sub strategi 11), SK positif (sub strategi 12), SK positif (sub strategi 14), SK positif (sub strategi 15), SK negatif (sub strategi 1), SK negatif (sub strategi 3), SK negatif (sub strategi 4), SK negatif (sub strategi 5), SK negatif (sub strategi 6), SK negatif (sub strategi 7), SK negatif (sub strategi 8), SK negatif (sub strategi 10), bald off record strategy (sub strategi 1), bald off record strategy (sub strategi 2), bald off record strategy (sub strategi 3), bald off record strategy (sub strategi 13), dan bald off record strategy (sub strategi 15).
2. Ungkapan yang digunakan pada SK dalam percakapan tingkat shokyuu adalah 〜 ndesuka ( んですか), 〜desuka (〜ですか), dan desu ne (〜 ですね). Sedangkan ungkapan yang digunakan pada SK dalam percakapan tingkat chuukyuu adalah Chotto te mo ii desuka (ちょっと〜てもいいですか), Chotto te itadakenaideshouka (ちょっ と〜ていただけないでしょうか), Chotto te itadakemasenka (ちょっと〜 ていただけませんか), mashouka (〜 ましょうか), dou yatte baii? (どうや って〜ばいい?), ba iin jya nai (〜ば いいんじゃない), masenka (〜ません

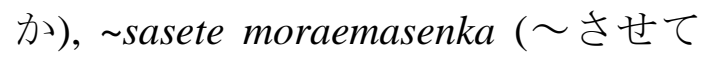
もらえませんか), 〜tara ii deshouka ( たらいいでしょうか), naideshouka (〜ないでしょうか), 〜njyanai deshouka (〜んじゃないでしょうか), 〜toiu no wa dou (〜というのはどう?), 〜tara dou? (〜たらどう?).

\section{DAFTAR PUSTAKA}

Black, Elizabeth. 2011. Stilistika Pragmatis. Yogyakarta: Pustaka Pelajar

Brown, P and Stephen Levinson. 1987. Politeness: Some Universals In Language Usage. Cambridge: Cambridge University Press

Chaer, Abdul. 2010. Kesantunan Berbahasa. Jakarta: Rineka Cipta

Cummings, Louise. 2007. Pragmatik: Sebuah Prespektif Multidisipliner. Yogyakarta: Pustaka Pelajar

Levinson, Stephen C. 1995. Pragmatics. Melbourne: The Press Syndicate of The University of Cambirdge.

Nadar, F.X., 2009.Pragmatik \& Pragmatik. Yogyakarta: Graha Ilmu

Minna No Nihongo chuukyuu 1. 2008. Tokyo: 3A Corporation

Minna No Nihongo shokyu 2. 1998. Tokyo: 3A Corporation 


\section{Lampiran 1.}

Data Tuturan yang mengandung Strategi Kesantunan dari buku Minna no Nihongo Shokyuu II

\begin{tabular}{|c|c|c|c|}
\hline BAB & Tuturan & $\begin{array}{c}\text { No } \\
\text { Data }\end{array}$ & Strategi Kesantunan \\
\hline \multirow[t]{4}{*}{26} & $\begin{array}{l}\text { あのう、ごみを捨てないんですが、どこに出したら } \\
\text { いいですか。 }\end{array}$ & $26-1$ & SK negatif (sub strategi 1) \\
\hline & それから、お湯が出ないんですが... & $26-2$ & $\begin{array}{l}\text { Bald off record strategy (sub } \\
\text { strategi } 2 \text { ) }\end{array}$ \\
\hline & $\begin{array}{l}\text { •・・困ったなあ。電話がないんです。連絡してい } \\
\text { ただけませんか }\end{array}$ & $26-3$ & SK negatif ( sub strategi 1) \\
\hline & すみません。お願いします。 & $26-4$ & SK negatif (sub strategi 6) \\
\hline \multirow[t]{5}{*}{27} & $\begin{array}{l}\text { このテーブルは面白いデザインですね。アメリカで } \\
\text { 買ったんですか。 }\end{array}$ & $27-1$ & SK positif (sub strategi 1) \\
\hline & えつ、本当ですか。 & $27-2$ & SK positif (sub strategi 2) \\
\hline & へえ。じゃ、あの本棚も作ったんですか。 & $27-3$ & SK positif (sub strategi 2) \\
\hline & $\begin{array}{l}\text { すごいですね。ミラーさん、何でも作れるんです } \\
\text { ね。 }\end{array}$ & $27-4$ & SK positif (sub strategi 2) \\
\hline & 素晴らしい夢ですね。 & $27-5$ & SK positif (sub strategi 2) \\
\hline \multirow[t]{7}{*}{28} & ミラーさん、ちょつとお願いがあるんですが。 & $28-1$ & SK negatif (sub strategi 4) \\
\hline & $\begin{array}{l}\text { 息子に 英語を 教えていただけませんか。 オース } \\
\text { トラリアへホームステイに行くんですが、会話が出 } \\
\text { 来ないんですよ。 }\end{array}$ & $28-2$ & SK negatif (sub strategi 1) \\
\hline & 教えてあげたいんですけど、ちよつと時間が. . . & $28-3$ & $\begin{array}{l}\text { Bald off record strategy (sub } \\
\text { strategi 15) }\end{array}$ \\
\hline & $\begin{array}{l}\text { お茶でも飲みながら おしやべりしていただけませ } \\
\text { んか。 }\end{array}$ & $28-4$ & SK negatif (sub strategi 1) \\
\hline & 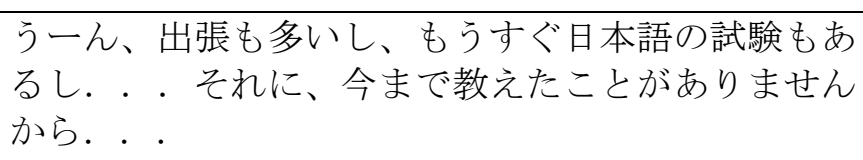 & $28-5$ & $\begin{array}{l}\text { Bald off record strategy (sub } \\
\text { strategi 1) }\end{array}$ \\
\hline & だめですか。じゃ、残念ですが... & $28-6$ & SK negatif (sub strategi 7) \\
\hline & どうもすみません。 & $28-7$ & SK negatif (sub strategi 6) \\
\hline \multirow[t]{3}{*}{29} & $\begin{array}{l}\text { すみません。今の電車に忘れ物をしてしまったんで } \\
\text { すが.. . }\end{array}$ & $29-1$ & $\begin{array}{l}\text { Bald off record strategy (sub } \\
\text { strategi 2) }\end{array}$ \\
\hline & $\begin{array}{l}\text { じや、すぐ連絡しますから、ちよっと待っていてく } \\
\text { ださいね }\end{array}$ & $29-2$ & Bald on record strategy \\
\hline & 今、四ツ谷駅にありますが、どうしますか。 & $29-3$ & SK negatif (sub strategi 1) \\
\hline
\end{tabular}




\begin{tabular}{|c|c|c|c|}
\hline & じや、四ツ谷駅の事務所へ行ってください & $29-4$ & Bald on record strategy \\
\hline \multirow[t]{5}{*}{30} & $\begin{array}{l}\text { 資料はあとで 見ておきますから。そこに置いとい } \\
\text { て下さい。 }\end{array}$ & $30-1$ & Bald on record strategy \\
\hline & 何かご希望がありますか & $30-2$ & SK positif (sub strategi 15) \\
\hline & $\begin{array}{l}\text { そうですね。一度ブロードウェイでミュージカルを } \\
\text { 見たいと思うんですが }\end{array}$ & $30-3$ & $\begin{array}{l}\text { Bald off record strategy (sub } \\
\text { strategi 3) }\end{array}$ \\
\hline & $\begin{array}{l}\text { それはいいですね。チケットを予約しておきましょ } \\
\text { うか。 }\end{array}$ & $30-4$ & SK negatif (sub strategi 1) \\
\hline & ええ、お願いします。 & $30-5$ & SK negatif (sub strategi 7) \\
\hline \multirow[t]{5}{*}{31} & $\begin{array}{l}\text { A: 実は大阪の本社に転勤なんです。 } \\
\text { B: 本社ですか。それは、おめでとうございます。で } \\
\text { もどうして独身になるんですか。 }\end{array}$ & $31-1$ & SK positif (sub strategi 5) \\
\hline & ええっ、いっしょに行かないんですか。 & $31-2$ & SK positif (sub strategi 2) \\
\hline & へえ、別々に住むんですか。 & $31-3$ & SK positif (sub strategi 2) \\
\hline & 大変ですね & $31-4$ & SK positif (sub strategi 2) \\
\hline & それもいいですね & $31-5$ & SK positif (sub strategi 5) \\
\hline \multirow[t]{5}{*}{32} & $\begin{array}{l}\text { シュミットさん、どうしたんですか。元気がありま } \\
\text { せんね }\end{array}$ & $32-1$ & SK positif (sub strategi 1) \\
\hline & $\begin{array}{l}\text { それはいけませんね。病気かもしれませんから、一 } \\
\text { 度病院で診てもらったほうがいいですよ。 }\end{array}$ & $32-2$ & SK positif (sub strategi 2) \\
\hline & $\begin{array}{l}\text { 特に、悪いところは ありませんよ。仕事は忙しい } \\
\text { ですか? }\end{array}$ & $32-3$ & Bald on record strategy \\
\hline & 働き過ぎですね & $32-4$ & SK positif (sub strategi 2) \\
\hline & $\begin{array}{l}\text { 無理をしないほうがいいですよ } \\
\text { 少し休みを取って、ゆっくりしてください }\end{array}$ & $32-5$ & Bald on record strategy \\
\hline 33. & すみません。 & $33-1$ & SK negatif (sub strategi 6) \\
\hline \multirow[t]{4}{*}{34.} & 一度茶道が見たいんですが。. . & $34-1$ & $\begin{array}{l}\text { Bald off record startegy (sub } \\
\text { strategi 3) }\end{array}$ \\
\hline & じや、来週の土曜日一緒に行きませんか & $34-2$ & SK negatif (sub strategi 1) \\
\hline & $\begin{array}{l}\text {-渡辺さん、お茶をたててください } \\
\text {-クララさん、お菓子を先にどうぞ。 }\end{array}$ & $34-3$ & Bald on record strategy \\
\hline & えっ、先にお菓子を食べるんですか & $34-4$ & SK positif (sub strategi 5) \\
\hline
\end{tabular}




\begin{tabular}{|c|c|c|c|}
\hline & $\begin{array}{l}\text { ええ。甘いお菓子を食べたあとで、お茶を飲むとお } \\
\text { いしいんですよ }\end{array}$ & $34-5$ & SK negatif (sub strategi 8) \\
\hline & そうですか & $34-6$ & SK positif (sub strategi 5) \\
\hline & では、お茶を飲みましょう & $34-7$ & SK positif (sub strategi 12) \\
\hline & $\begin{array}{l}\text { 私がするとおりに、してくださいね. まず、右手で } \\
\text { お茶碗を取って、左手に載せます。 }\end{array}$ & $34-8$ & Bald on record strategy \\
\hline & 次にお茶碗を 2 回回して、それから飲みます。 & $34-9$ & Bald on record strategy \\
\hline 35. & 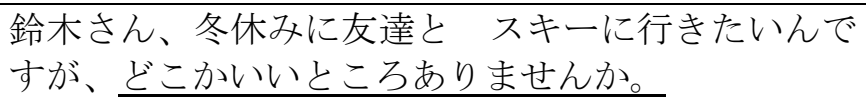 & $35-1$ & SK negatif (sub strategi 1) \\
\hline & $\begin{array}{l}\text { それなら、草津か志賀高原がいいと思いますよ。温 } \\
\text { 泉もあるし. . . }\end{array}$ & $35-2$ & $\begin{array}{l}\text { Bald off record strategy (sub } \\
\text { strategi 15) }\end{array}$ \\
\hline & $\begin{array}{l}\mathrm{A} \text { ：どうやって行くんですか。 } \\
\text { Q：J Rでも 行けますが、バスなら、朝着きます } \\
\text { から、便利ですよ。 }\end{array}$ & $35-3$ & SK negatif (sub strategi 1) \\
\hline & $\begin{array}{l}\mathrm{A} \text { ：どちらが安いんですか。 } \\
\mathrm{Q} \text { ：さあ.。・。旅行社へ行けばもっと詳しいこと } \\
\text { が分かります。 }\end{array}$ & $35-4$ & $\begin{array}{l}\text { Bald off record startegy (sub } \\
\text { strategi 2) }\end{array}$ \\
\hline & $\begin{array}{l}\text { A : それから、スキーの道具や服は何も持っていな } \\
\text { いんですが... } \\
\text { Q : 全部、スキー場で借りられますよ。心配なら、 } \\
\text { 旅行社で予約も出来るし. . . }\end{array}$ & $35-5$ & $\begin{array}{l}\text { Bald off record startegy (sub } \\
\text { strategi 2) }\end{array}$ \\
\hline 36 & $\begin{array}{l}\text { お元気ですね。何か特別なことをしていらつしやい } \\
\text { ますか。 }\end{array}$ & $36-1$ & SK positif (sub strategi 1) \\
\hline & すごいですね。食べ物は? & $36-2$ & $\begin{array}{l}\text { SK positif dengan cara } \\
\text { melebih-lebihkan tuturan (sub } \\
\text { strategi 2) }\end{array}$ \\
\hline & なんでもチャレンジする気持ちが大切なんですね。 & $36-3$ & SK positif (sub strategi 7) \\
\hline 37 & $\begin{array}{l}\text { すごい技術ですね。でも、どうして海の上に作った } \\
\text { んですか }\end{array}$ & $37-1$ & SK positif (sub strategi 2) \\
\hline & このビルも面白いデザインですね。 & $37-2$ & SK positif (sub strategi 2) \\
\hline 38 & あ、すみません。そこにおいといて下さい。 & $38-1$ & SK negatif (sub strategi 6) \\
\hline & 先生の研究室はいつもきれいですね & $38-2$ & SK positif (sub strategi 1) \\
\hline & $\begin{array}{l}\text { 本もきちんと並べてあるし、物も整理して置いてあ } \\
\text { るし.．．整理するのが上手なんですね。 }\end{array}$ & $38-3$ & SK positif (sub strategi 2) \\
\hline & へえ、すごいですね。 & $38-4$ & SK positif (sub strategi 2) \\
\hline
\end{tabular}




\begin{tabular}{|c|c|c|c|}
\hline & $\begin{array}{l}\text { あまり売られませんでしたけどね。よかったら、一 } \\
\text { 冊持って来ましょうか }\end{array}$ & $38-5$ & SK negatif (sub strategi 1) \\
\hline & あ、本を持って来るのを忘れました。すみません。 & $38-6$ & $\begin{array}{ll}\text { SK negatif } & \text { dengan cara } \\
\text { meminta maaf } & (6)\end{array}$ \\
\hline & $\begin{array}{l}\text { いいですよ。でも、回覽にはんこを押すのを忘れな } \\
\text { いで下さい。 }\end{array}$ & $38-7$ & SK positif (sub strategi 14) \\
\hline \multirow[t]{4}{*}{39} & ミラーさん、どうしたんですか。 & $39-1$ & Bald on record strategy \\
\hline & バスの事故ですか & $39-2$ & SK positif (sub strategi 5) \\
\hline & $\begin{array}{l}\text { それは大変でしたね。連絡がないので、みんな心配 } \\
\text { していたんですよ。 }\end{array}$ & $39-3$ & SK positif (sub strategi 2) \\
\hline & どうもすみませんでした。 & $39-4$ & SK negatif (sub strategi 6) \\
\hline \multirow[t]{3}{*}{40} & $\begin{array}{l}\text { 先生、ハンスは学校でどうでしょうか。友達ができ } \\
\text { たかどうか心配なんですが... }\end{array}$ & $40-1$ & $\begin{array}{l}\text { Bald off record startegy (sub } \\
\text { strategi 15) }\end{array}$ \\
\hline & ハンス君が学校でどんな様子か、ぜひ見てください & $40-2$ & Bald on record strategy \\
\hline & 分かりました。これからもよろしくお願いします & $40-3$ & SK negatif (sub strategi 7) \\
\hline \multirow[t]{5}{*}{41} & 小川さん、ちよっと お願いがあるんですが. & $41-1$ & SK negatif (sub strategi 4) \\
\hline & $\begin{array}{l}\text { 実は今日の夕方 デパートから荷物が届く予定なん } \\
\text { ですが、出かけなければならない用事が出来てしま } \\
\text { ったんです。 }\end{array}$ & $41-2$ & $\begin{array}{l}\text { Bald off record strategy (sub } \\
\text { strategi 2) }\end{array}$ \\
\hline & $\begin{array}{l}\text { それで 申し訳ありませんが、預かっておいていた } \\
\text { だけませんか。 }\end{array}$ & $41-3$ & SK negatif (sub strategi 6) \\
\hline & すみません。帰ったら、すぐ取りに来ます & $41-4$ & SK positif (sub strategi 10) \\
\hline & 宜しくお願いします & $41-5$ & SK negatif (sub strategi 7) \\
\hline \multirow[t]{2}{*}{42} & 明日です。楽しみですね & $42-1$ & SK positif (sub strategi 3) \\
\hline & ヘえ、独身の人はいいですね & $42-2$ & SK positif (sub strategi 5) \\
\hline \multirow[t]{4}{*}{43} & お見合いの会社があるんですか。 & 43-1 & SK positif (sub strategi 2) \\
\hline & へえ、面白そうですね & $43-2$ & SK positif (sub strategi 2) \\
\hline & ハンサムだし、優しそうだし、すてきな人ですね。 & $43-3$ & SK positif (sub strategi 6) \\
\hline & ヘえ、コンピューターはすごいですね & $43-4$ & SK positif (sub strategi 2) \\
\hline \multirow[t]{2}{*}{44} & いらっしゃいませ。今日はどうなさいますか & $44-1$ & SK negatif (sub strategi 1) \\
\hline & $\begin{array}{l}\text { カット、お願いします } \\
\end{array}$ & $44-2$ & SK negatif(sub strategi 7) \\
\hline
\end{tabular}




\begin{tabular}{|c|c|c|c|}
\hline & じや、シャンプーをしますから、こちらへどうぞ & $44-3$ & $\begin{array}{l}\text { Bald off record strategy (sub } \\
\text { strategi 1) }\end{array}$ \\
\hline & カットはどいいうふうになさいますか & $44-4$ & SK negatif (sub strategi 5) \\
\hline & この写真みたいにしてください & $44-5$ & Bald on record strategy \\
\hline & あ、すてきですね & $44-6$ & SK positif (sub strategi 1) \\
\hline & 前の長さはこれでよろしいでしょうか & $44-7$ & SK negatif (sub strategi 5) \\
\hline & どうもお疲れさまでした。いかがですか & $44-8$ & SK negatif (sub strategi 5) \\
\hline 45 & $\begin{array}{l}\text { 皆さん、このマラソンは健康マラソンですから、無 } \\
\text { 理をしないでください }\end{array}$ & $45-1$ & Bald on record strategy \\
\hline & もし気分が悪くなったら、係員に言ってください & $45-2$ & Bald on record strategy \\
\hline & $\begin{array}{l}\text { コースを間違えた場合は、元の所に戻って続けてく } \\
\text { ださい }\end{array}$ & $45-3$ & Bald on record strategy \\
\hline & $\begin{array}{l}\text { その場合は、近くの係員に名前を言ってから、帰っ } \\
\text { てください。 }\end{array}$ & $45-4$ & Bald on record strategy \\
\hline & $\begin{array}{l}\text { あのう、途中で止めたい場合は、どうしたらいいで } \\
\text { すか。 }\end{array}$ & $45-5$ & SK negatif (sub strategi 1) \\
\hline & 2 位だったんですか。すごいですね。 & $45-6$ & SK positif (sub strategi 2) \\
\hline & また来年がありますよ & $45-7$ & SK positif (sub strategi 11) \\
\hline 46 & $\begin{array}{l}\text { あのう、ガスレンジの調子がおかしいんです } \\
\text { が.... }\end{array}$ & $46-1$ & $\begin{array}{l}\text { Bald off record strategy (sub } \\
\text { strategi 2) }\end{array}$ \\
\hline & 危ないので、早く見に来てくれませんか。 & $46-2$ & SK negatif (sub strategi 1) \\
\hline & ご住所とお名前をお願いします & $46-3$ & SK negatif (sub strategi 7) \\
\hline & $\begin{array}{l}5 \text { 時ごろにガスレンジを見に来てくれるはずなんで } \\
\text { すが、まだですか。 }\end{array}$ & $46-4$ & $\begin{array}{l}\text { Bald off record strategy (sub } \\
\text { strategi 2) }\end{array}$ \\
\hline & すみません、どちら様でしょうか & $46-5$ & $\begin{array}{l}\text { SK negatif menggunakan } \\
\text { bentuk tidak langsung (1) }\end{array}$ \\
\hline & ちょっとお待ちください & $46-6$ & Bald on record strategy \\
\hline & $\begin{array}{l}\text { お待たせしました。今 そちらに 向かっていると } \\
\text { ころです。あと 十分ほどお待ちください。 }\end{array}$ & $46-7$ & Bald on record strategy \\
\hline 47 & A：あっ、渡辺さん、ちよっと待って。 & $47-1$ & Bald on record strategy \\
\hline & Q Q：すみません、ちよっと急ぎますから。 & $47-2$ & SK negatif (sub strategi 6) \\
\hline 48 & $\begin{array}{l}\text { A：課長、今 お忙しいですか。 } \\
\text { B ：いいえ、どうぞ }\end{array}$ & $48-1$ & SK negatif (sub strategi 1) \\
\hline
\end{tabular}




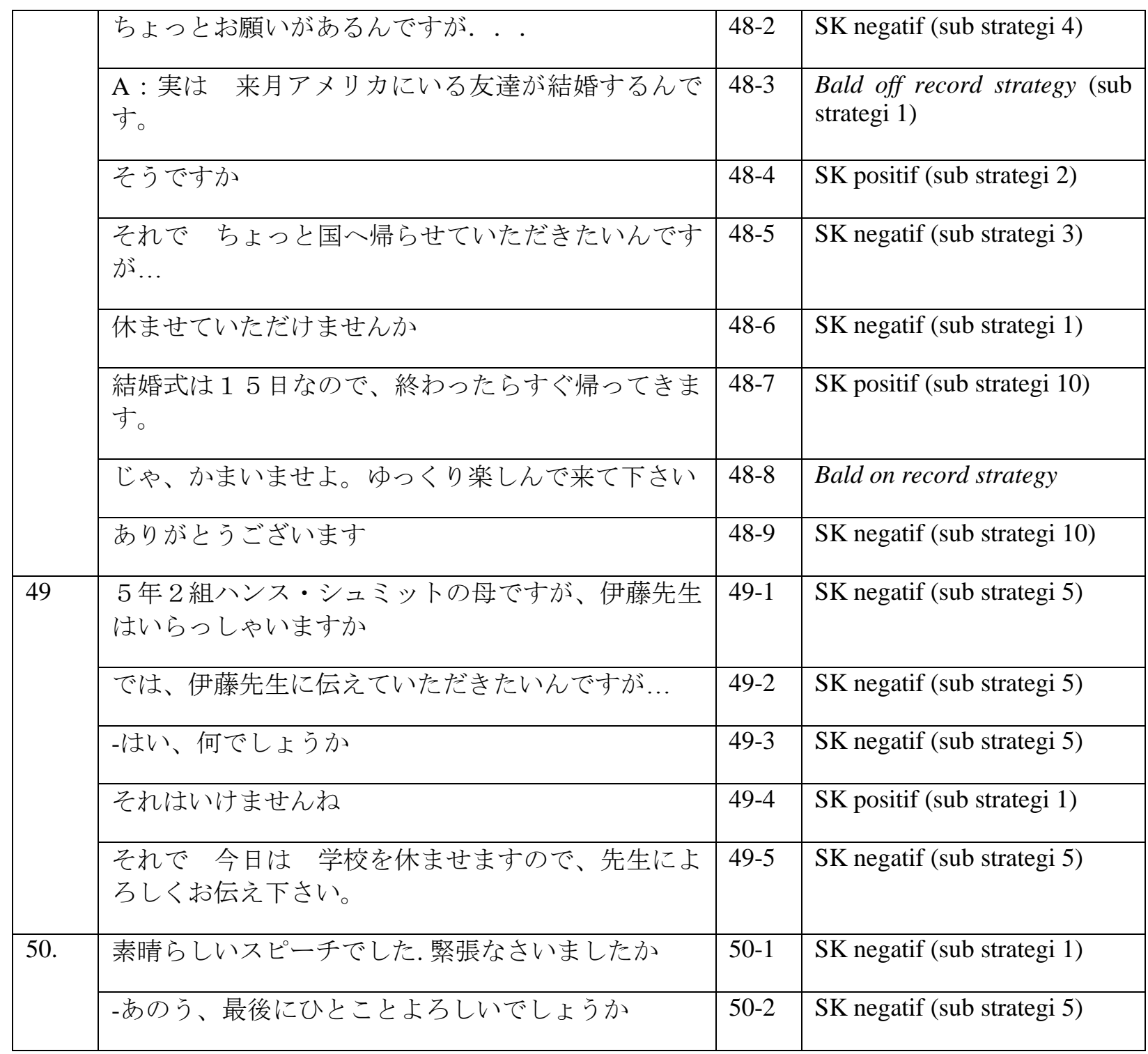


Lampiran 2. Data Tuturan yang mengandung Strategi Kesantunan dari buku Minnano Nihongo Chuиkуии I

\begin{tabular}{|c|c|c|c|}
\hline $\mathrm{BAB}$ & Tuturan & & Strategi Kesantunan \\
\hline \multirow[t]{8}{*}{1} & 佐野さん、ちょっとお聞きしてもいいですか。 & $1-1$ & SK negatif (sub strategi 1) \\
\hline & わあ、すごいですね。実はお願いがあるんですが & $1-2$ & SK positif (sub strategi 1) \\
\hline & $\begin{array}{l}\text { あのう、ちょっとお宅を見せていただけないでしょ } \\
\text { うか。 }\end{array}$ & $1-3$ & SK negatif (sub strategi 1) \\
\hline & $\begin{array}{l}\text { 日本の畳文化についてレポートを書こうと思ってい } \\
\text { るんです。 }\end{array}$ & $1-4$ & $\begin{array}{l}\text { strategi off record dengan } \\
\text { memberikan alasan (sub1) }\end{array}$ \\
\hline & 何とかお願いできないでしょうか。 & $1-5$ & SK negatif (sub strategi 7) \\
\hline & それなら、お寺とか旅館とか. . . & $1-6$ & $\begin{array}{l}\text { Bald off record strategy } \\
\text { (sub strategi 15) }\end{array}$ \\
\hline & ありがとうございます。助かります。 & $1-7$ & SK negatif (sub strategi 7) \\
\hline & お陰様で、いいレポートを書けました。 & $1-8$ & SK negatif (sub strategi 10) \\
\hline \multirow[t]{2}{*}{2} & ちょっと、お待ちください。 & $2-1$ & Bald on record strategy \\
\hline & $\begin{array}{l}\text { お忙しいところ、すみません。ちょつと教えていた } \\
\text { だけませんか }\end{array}$ & $2-2$ & SK negatif (sub strategi 1) \\
\hline \multirow[t]{8}{*}{3} & イーと申しますが、森先生、お願いします。 & $3-1$ & SK negatif (sub strategi 7) \\
\hline & はい、お待ちください。 & $3-2$ & Bald on record strategy \\
\hline & $\begin{array}{l}\text { 乗る電車を間違えてしまって、30 分ぐらい遅れそう } \\
\text { なんです。 }\end{array}$ & $3-3$ & $\begin{array}{l}\text { Bald off record strategy } \\
\text { (sub strategi 2) }\end{array}$ \\
\hline & そうですか。私は 2 時から授業なんですが。. . & $3-4$ & $\begin{array}{l}\text { Bald off record strategy } \\
\text { (sub strategi 1) }\end{array}$ \\
\hline & $\begin{array}{l}\text { 申し訳ありません。わざわざお時間をとっていただ } \\
\text { いたのに。 }\end{array}$ & $3-5$ & SK negatif (sub strategi 7) \\
\hline & $\begin{array}{l}\text { あのう、論文のことでいろいろご相談したいので、 } \\
\text { 出来れば先生のご都合のよい日に変更させていただ } \\
\text { けないでしょうか。 }\end{array}$ & $3-6$ & SK negatif (sub strategi 1) \\
\hline & $\begin{array}{l}\text { じや、来週の月曜日、授業が終わった後お会いする } \\
\text { ことにしましょう }\end{array}$ & 3-7 & Bald on record strategy \\
\hline & 午後 6 時ごろおいでください & $3-8$ & Bald on record strategy \\
\hline \multirow[t]{3}{*}{4.} & $\begin{array}{l}\text { 戻りましたら、こちらからお電話差し上げましょう } \\
\text { か。 }\end{array}$ & $4-1$ & SK negatif (sub strategi 1) \\
\hline & あのう、恐れ入りますが、伝言お願いできますか。 & $4-2$ & SK negatif (sub strategi 6) \\
\hline & 申しわけありませんが、そのようにお伝えいただけ & $4-3$ & SK negatif (sub strategi 6) \\
\hline
\end{tabular}




\begin{tabular}{|c|c|c|c|}
\hline & \multicolumn{3}{|l|}{ ませんか。 } \\
\hline & よろしくお願いいたします。 & $4-4$ & SK negatif (sub strategi 7) \\
\hline \multirow[t]{5}{*}{5} & $\begin{array}{l}\text { 池田さん、あした、さくら芸実センターへ行こうと } \\
\text { 思っているんだけど、どうやって行けばいい。 }\end{array}$ & $5-1$ & SK negatif (sub strategi 1) \\
\hline & $\begin{array}{l}\text { あそこだったら、地下鉄で行くといいよ。千里で乗 } \\
\text { り換えて、西千里で降りればいいんじゃない。 }\end{array}$ & $5-2$ & SK negatif (sub strategi 1) \\
\hline & $\begin{array}{l}\text { あのう、さくら芸術センターへ行きたいんですが、 } \\
\text { どう行ったらいいでしょうか。 }\end{array}$ & $5-3$ & SK negatif (sub strategi 1) \\
\hline & すみません & $5-4$ & SK negatif (sub strategi 7) \\
\hline & $\begin{array}{l}100 \text { メートルぐらい先で道が二つに分かれています } \\
\text { から、右のほうへ行ってください }\end{array}$ & $5-5$ & Bald on record strategy \\
\hline \multirow[t]{8}{*}{6} & 課長、今ちよっとよろしいでしょうか。 & $6-1$ & SK negatif (sub strategi 1) \\
\hline & そう、残念でしたね。 & $6-2$ & SK positif (sub strategi 2) \\
\hline & ああ、いいですね。 & $6-3$ & SK positif (sub strategi 2 ) \\
\hline & $\begin{array}{l}\text { 今の私の仕事には、もう少し高いレベルの日本語が } \\
\text { 必要だと思うんです。出来れば会社の費用でこの学 } \\
\text { 校へ行かせていただきたいんですが、どうでしょう } \\
\text { か。 }\end{array}$ & $6-4$ & SK negatif (sub strategi 1) \\
\hline & ちょっと高いですね & $6-5$ & $\begin{array}{l}\text { Bald off record strategy } \\
\text { (sub strategi 13) }\end{array}$ \\
\hline & $\begin{array}{l}\text { もし、全額が無理なら会社に社員研修の制度があり } \\
\text { ますよね。あれを利用できないでしょうか。 }\end{array}$ & $6-6$ & SK negatif (sub strategi 1) \\
\hline & $\begin{array}{l}5 \text { 時半に出れば、間に合います。ぜひ行かせて下さ } \\
\text { い。お願いします。 }\end{array}$ & $6-7$ & SK negatif (sub strategi 7) \\
\hline & それでは、書類を出してください & $6-8$ & Bald on record strategy \\
\hline \multirow[t]{5}{*}{7} & $\begin{array}{l}\text { 来週の金曜日にね、市民会館で着物の着付け教室が } \\
\text { あるんですけど、一緒に行ってみませんか。 }\end{array}$ & $7-1$ & SK negatif (sub strategi 1) \\
\hline & $\begin{array}{l}\text { 本当ですか。前から一度着てみたいとって思ったん } \\
\text { です。ぜひお願いします。 }\end{array}$ & $7-2$ & SK negatif (sub strategi 7) \\
\hline & $\begin{array}{l}\text { じゃ、 } 3 \text { 時からなので、 } 2 \text { 時半に駅前で待ち合わせ } \\
\text { ましょう }\end{array}$ & $7-3$ & SK positif (sub strategi 12) \\
\hline & $\begin{array}{l}\text { うん、国際交流のパーティーがあるんだけど、一緒 } \\
\text { にどうかなと思って。 }\end{array}$ & $7-4$ & $\begin{array}{l}\text { strategi tidak langsung /off } \\
\text { record strategy (sub } \\
\text { strategi2) }\end{array}$ \\
\hline & $\begin{array}{l}\text { らーん。行きたいけど.．月曜日にゼミで発表す } \\
\text { ることになったってて、その準備をしなくちやいけ } \\
\text { ないんです。 }\end{array}$ & $7-5$ & $\begin{array}{l}\text { Bald off record strategy } \\
\text { (sub strategi 1) }\end{array}$ \\
\hline
\end{tabular}




\begin{tabular}{|c|c|c|c|}
\hline & $\begin{array}{l}\text { せっかく誘っていただいたのに、申し訳ありませ } \\
\text { ん。 }\end{array}$ & $7-6$ & SK negatif (sub strategi 6) \\
\hline & 今回は遠慮させてください & $7-7$ & Bald on record strategy \\
\hline 8 & $\begin{array}{l}\text { あのう、買い物にしている間に、子供が迷子になっ } \\
\text { ちゃったんです。 }\end{array}$ & $8-1$ & $\begin{array}{l}\text { strategi tidak langsung (sub } \\
\text { strategi 2) }\end{array}$ \\
\hline & 着ているものなど、教えてください。 & $8-2$ & Bald on record strategy \\
\hline & $\begin{array}{l}\text { あのう、姪は日本語が全然わからないんです } \\
\text { が、。. }\end{array}$ & $8-3$ & $\begin{array}{l}\text { Bald off record strategy } \\
\text { (sub strategi 2) }\end{array}$ \\
\hline & $\begin{array}{l}\text { よろしくお願いします。すみません。見つかるま } \\
\text { で、こちらで待たせてもらえませんか。 }\end{array}$ & $8-4$ & SK negatif (sub strategi 1) \\
\hline 9 & $\begin{array}{l}\text { 電子辞書をお探しですか. · ·言葉の意味と漢字の } \\
\text { 読み方を調べたいんです。 }\end{array}$ & $9-1$ & $\begin{array}{l}\text { Bald off record strategy } \\
\text { (sub strategi 2) }\end{array}$ \\
\hline & $\begin{array}{l}\text { でも、そのフラット社のは例文が少ないですね。意 } \\
\text { 味の説明だけじゃなくて、例文がたくさん載ってい } \\
\text { るのが欲しいんです。ほかにいいの、ありません } \\
\text { か。 }\end{array}$ & $9-2$ & $\begin{array}{l}\text { Bald off record strategy } \\
\text { (sub strategi 1) }\end{array}$ \\
\hline & $\begin{array}{l}\text { 入っている辞書の数はこれより少なくてもかまいま } \\
\text { せんか。 }\end{array}$ & $9-3$ & SK negatif (sub strategi 3) \\
\hline & $\begin{array}{l}\text { それでしたら、トップ社のがよろしいんじゃないで } \\
\text { しょうか。 }\end{array}$ & $9-4$ & SK negatif (sub strategi 1) \\
\hline 10 & あのう、ワットさん、自転車のことなんですけど。 & $10-1$ & $\begin{array}{l}\text { Bald off record strategy } \\
\text { (sub strategi 3) }\end{array}$ \\
\hline & $\begin{array}{l}\text { 自転車は、階段の前に置いてはいけないことになっ } \\
\text { てるんですよ。 }\end{array}$ & $10-2$ & SK negatif (sub strategi 8) \\
\hline 11 & $\begin{array}{l}\text { いろいろ考えてるんですがどこかお勧めのところ、 } \\
\text { ありませんか }\end{array}$ & $11-1$ & SK negatif (sub strategi 1) \\
\hline & ちょっと遠いけど、沖縄というのはどう？ & $11-2$ & SK negatif (sub strategi 1) \\
\hline & $\begin{array}{l}\text { それも悪くないですね。あのう、北海道なんかどう } \\
\text { かなと思ってたんですが。 }\end{array}$ & $11-3$ & SK positif (sub strategi 6) \\
\hline & $\begin{array}{l}\text { ああ、北海道もいいね。すずしくて。でも北海道へ } \\
\text { 行くなら、やっぱり冬のほうがいいな。雪祭りとか } \\
\text { 流水とか、北海道らしい景色が見られるし、. . }\end{array}$ & $11-4$ & SK positif (sub strategi 5) \\
\hline & $\begin{array}{l}\text { それもそうですね。けど、北海道も沖縄も高そうで } \\
\text { すね。 }\end{array}$ & $11-5$ & SK positif (sub strategi 6) \\
\hline & パックツアーを利用したらどう？個人で行くよりず & $11-6$ & SK negatif (sub strategi 1) \\
\hline
\end{tabular}




\begin{tabular}{|c|c|c|c|}
\hline & \multicolumn{3}{|l|}{ っと安いですよ。 } \\
\hline & $\begin{array}{l}\text { そんなのがあるんですか。じゃ、帰りに旅行会社に } \\
\text { 寄って、調べてみます。 }\end{array}$ & $11-7$ & SK positif (sub strategi 5) \\
\hline \multirow[t]{9}{*}{12} & それは大変でしたね。 & $12-1$ & SK positif (sub strategi (2) \\
\hline & あの、ちょつとお話があるんですが. & $12-2$ & SK negatif (sub strategi 4) \\
\hline & $\begin{array}{l}\text { 下の野村さんから苦情があってね㸚。夜遅く洗濯機の } \\
\text { 音が聞こえて寝られないそですよ。 }\end{array}$ & $12-3$ & $\begin{array}{l}\text { Bald off record strategy } \\
\text { (sub strategi 2) }\end{array}$ \\
\hline & $\begin{array}{l}\text { それは分かりますけど、あまり遅い時間に洗濯され } \\
\text { るとちょっと. . . 。子供が誛る時間なので。 }\end{array}$ & $12-4$ & $\begin{array}{l}\text { Bald off record strategy } \\
\text { (sub strategi 15) }\end{array}$ \\
\hline & $\begin{array}{l}\text { すみません。何時ごろまでならよろしいでしょう } \\
\text { か。 }\end{array}$ & $12-5$ & SK negatif (sub strategi 1) \\
\hline & 出来れば 10 時ごろまでならよろしでしょうか。 & $12-6$ & SK negatif (sub strategi 1) \\
\hline & 出来れば 10 時ごろまでにしてもらえますか。 & $12-7$ & SK negatif (sub strategi 1) \\
\hline & $\begin{array}{l}\text { わかりました。そのころまでには済ませるようにし } \\
\text { ます }\end{array}$ & $12-8$ & SK positif (sub strategi 10 ) \\
\hline & おお願いします & $12-9$ & SK negatif (sub strategi 6) \\
\hline
\end{tabular}

